\title{
ASSOCIATIONS BETWEEN VARIATIONS IN TPH1, TPH2 AND SLC6A4 GENES AND POSTPARTUM DEPRESSION: A STUDY IN THE JORDANIAN POPULATION
}

\author{
Khabour $\mathrm{OF}^{1}$, Amarneh $\mathrm{BH}^{2}$, Bani Hani $\mathrm{EA}^{3}$, Lataifeh $\mathrm{IM}^{4}$
}

\begin{abstract}
*Corresponding Author: Dr. Omar F. Khabour, Associate Professor of Molecular Genetics, Department of Medical Laboratory, Sciences, Jordan University of Science and Technology, PO Box 3030, Irbid 22110, Jordan; Tel.: +962-2-720-1000 ext. 23784; Fax: +962-2-720-1087; E-mail: khabour@just.edu.jo
\end{abstract}

\begin{abstract}
In this study, we investigated the association between tryptophan hydroxylase-1 (TPH1) (218A >C), tryptophan hydroxylase-2 (TPH2) (1463G>A) and serotonin carrier family 6, member 4 (SLC6A4) [long (L) vs. short (S)] gene polymorphisms with postpartum depression (PPD) in women from Jordan. A total of 370 postpartum (130 depressed and 240 non depressed) women volunteered for the study. Genotyping was carried out using restriction fragment length polymorphism (RFLP) for TPH1, amplification refractory mutation system (ARMS) for TPH2 and polymerase chain reaction (PCR) for SLC6A4 S and L. The Edinburgh postnatal depression scale was used to screen postpartum women. Both $\mathrm{S}$ and L alleles of SLC6A4 are common in Jordanian women (about 51.0 and 49.0\%, respectively), while allele $T P H 1-218 \mathrm{C}$ is more common $(64.0 \%)$ than allele A (37.0\%). Regarding TPH2, allele A is absent from the examined women. None of the examined polymorphisms were found to be associated with PPD $(p>0.05)$. However, depression history, preg-

\footnotetext{
${ }^{1}$ Department of Medical Laboratory Sciences, Jordan University of Science and Technology, Irbid, Jordan Science and Technology, Irbid, Jordan

${ }^{3}$ Department of Community and Mental Health Nursing, Jordan University of Science and Technology, Irbid, Jordan

${ }^{4}$ Department of Obstetrics and Gynecology Jordan University of Science and Technology, Irbid, Jordan
}

${ }^{2}$ Department of Applied Biological Sciences, Jordan University of
\end{abstract}

nancy problems and economic status were found to be significantly associated with PPD $(p<0.05)$. The results suggest that TPH1, TPH2 and SLC6A4 S and $\mathrm{L}$ polymorphisms do not seem to be important in Jordan for predisposing to PPD.

Keywords: Depression; Gene; Polymorphism; Post-partum depression (PPD); Serotonin.

\section{INTRODUCTION}

Postpartum depression (PPD) occurs in 20.0$50.0 \%$ of women who have recently given birth, and may extend during the first year after delivery [1,2]. The symptoms of PPD include feeling of being alone, sleep deprivation, decreased desire for food, regular occurrence of unstable, disproportional emotional displays, and to a lesser extent, recurrent thoughts of harming oneself and/or the child [1,2]. Depression is a complex disorder, such that environmental as well as genetic factors, may play a role in developing the disease.

The neurotransmitter serotonin plays a role in sleep, appetite, emotions, body temperature and blood pressure [3]. Disruption of serotonergic neurotransmission is implicated in the development of many psychiatric diseases such as depression and bipolar disorder [4]. Therefore, variations in genes involved in biosynthesis, transmission and metabolism of serotonin are candidates for predisposing to PPD. Among such candidates are tryptophan hydroxylase-1 (TPH1) (218A >C), and tryptophan hydroxylase-2 
(TPH2) $(1463 \mathrm{G}>\mathrm{A})$ genes that code for tryptophan hydroxylase, the rate limiting enzyme in the conversion of tryptophan into serotonin [5]. The TPHI gene is located on chromosome 11, spans $29 \mathrm{~kb}$, and has 11 exons [6]. The gene is expressed mainly in the pineal gland as well as in the peripheral tissues [7]. Among the polymorphisms of the TPHI gene is the $218 \mathrm{~A}>\mathrm{C}(\mathrm{rs} 1800532)$ variation in intron 7 that has been shown to affect the expression of the gene [8,9]. Variations in TPH1 including $218 \mathrm{~A}>\mathrm{C}$ polymorphism, have been shown to be associated with bipolar disorder, suicidal behavior, alcoholism, and aggression-related traits $[10,11]$. The $T P H 2$ gene is located on chromosome 12 and spans $93.5 \mathrm{~kb}$ with 11 exons. It is predominantly expressed in the brainstem [7]. Zhang et al. [12] identified a functional a polymorphism $(1463 \mathrm{G}>\mathrm{A})$ in the $T P H 2$ gene that results in substitution of a highly conserved arginine by a histidine (Arg441His) and the subsequent alterations in enzyme activity [12]. Genetic variations in $\mathrm{TPH} 2$ have been shown to be associated with suicide, attention-deficit and hyperactivity disorder, autism and depression $[13,14]$. Another candidate is serotonin transporter gene solute carrier, serotonin carrier family 6, member 4 (SLC6A4) which encodes the human serotonin transporter that plays an important role in terminating the synaptic action of serotonin and recycles it into the presynaptic neurotransmitter pool [15]. A long (L) and a short (S) variant in the transcriptional control region upstream of the SLC6A4 coding sequence was reported [16]. In vitro analysis showed that the basal activity of the $\mathrm{L}$ form was about three-fold higher than that of the $S$ variant [16]. This variant has been shown to be associated with neuroticism [17] and depression [18-20].

In this study, we investigated the association between TPH1, TPH2 and the SLC6A4 (L/S variant) with PPD in the Jordanian population. In addition, we examined the possible correlation between socio-demographic, intra-partum and psychosocial variables with PPD.

\section{MATERIALS AND METHODS}

Subjects. This prospective cross-sectional study involved 370 randomly selected postpartum women ( 240 controls and 130 depressed cases) from five maternity centers in Irbid, Jordan. Random selection was carried out based on locations of the clinics in the city and type of clinic (public $v s$. private). Women with pre existing psychiatric disorders were excluded from the study. Women were recruited 4 to 6 weeks after child delivery. Informed written consent was obtained from all subjects in accordance with the requirements of the Institutional Review Boards of Jordan University of Science and Technology, Irbid, Jordan.

Edinburgh Postnatal Depression Scale Questionnaire. An Arabic version of the Edinburgh Postnatal Depression Scale (EPDS) was used to screen postpartum women [21]. An EPDS score $>13$ was used as a criterion to indicate the presence of depression illness(es) [21]. This cut-off value has been reported to have high sensitivity and specificity. Several demographic variables were also included in the questionnaire to assess the possible correlation between PPD and some environmental factors such as maternal age, educational level, income satisfaction, number of children, delivery mode, depression history and pregnancy problems.

DNA Extraction. Venous blood samples were collected in EDTA tubes and obtained from all subjects. DNA was extracted using Promega wizard genomic DNA purification kit (Promega, Madison, WI, USA) according to the protocol provided by the manufacturer. DNA concentrations were measured using Smart-SpectTM3000 (Bio-Rad Laboratories, Hemel Hempstead, Hertfordshire, UK). Extracted DNA was stored at $-20^{\circ} \mathrm{C}$ until used.

Genotyping of the TPH1 (218A $>$ C) Polymorphism. TPH1 was analyzed using polymerase chain reaction (PCR) followed by the restriction fragment length polymorphism (RFLP) method. The TPHI gene fragment was amplified using primers described previously [22]. The reaction mixture of $25 \mu \mathrm{L}$ contained $5 \mathrm{ng}$ of genomic DNA, $1 \mu \mathrm{M}$ of each primer, green master mix (Promega), $1 \mathrm{mM}$ of spermidine and $\mathrm{H}_{2} \mathrm{O}$. The reaction mixture was initially denatured at $95^{\circ} \mathrm{C}$ for $5 \mathrm{~min}$., followed by 30 cycles at $95^{\circ} \mathrm{C}$ for 30 seconds, $55^{\circ} \mathrm{C}$ for 30 seconds and $72^{\circ} \mathrm{C}$ for 30 seconds. The PCR was completed by a final extension cycle at $72^{\circ} \mathrm{C}$ for $5 \mathrm{~min}$. Successful amplification of the fragment was confirmed by detection of a $847 \mathrm{bp}$ band on a $2.0 \%$ agarose gel. The restriction enzyme digestion was carried out overnight at $37^{\circ} \mathrm{C}$ in a $20 \mu \mathrm{L}$ volume reaction mixture containing $10 \mu \mathrm{L}$ of the amplified PCR product and 1 unit of $B f a 1$. The digested fragments were then separated using 2.0\% agarose gel electrophoresis and detected by ethidium bromide 
staining. The PCR product with the A allele remained uncut ( $847 \mathrm{bp}$ ), whereas the digested PCR product with the $\mathrm{C}$ allele gave fragments of 599 and $248 \mathrm{bp}$.

Genotyping of the TPH2 (1463G $>$ A) Polymorphism. Allele-specific PCR using amplification refractory mutation system (ARMS) method was used for analyzing the TPH2 G1463A polymorphism as described by Zhang et al. [12]. Only the G allele PCRspecific product was detected in the DNA obtained from participating women, while the A allele product was not detected. Validity of the ARMS results was achieved by sequencing of more than $10.0 \%$ of the PCR products using ABI PRISM ${ }^{\mathrm{TM}} 3.1$ automated sequencer (Life Technologies, Applied Biosystems, Foster City, CA, USA) as previously described [23].

Genotyping of the SLC6A4 (L/S) Polymorphism. The SLC6A4 (L/S) polymorphism was analyzed using PCR. Desired DNA target sequences, $469 \mathrm{bp}$ for the $\mathrm{S}$ allele and $513 \mathrm{bp}$ for the L allele, were amplified as described by Middledorp et al. [24]. The reaction mixture of $20 \mu \mathrm{L}$ contained $5 \mathrm{ng}$ of genomic DNA, $1 \mu \mathrm{M}$ of each primer, Promega green master mix, 2.0\% DMSO and $\mathrm{H}_{2} \mathrm{O}$. The reaction mixture was initially denatured at $94^{\circ} \mathrm{C}$ for 3 min., followed by 35 cycles at $94^{\circ} \mathrm{C}$ for 30 seconds, $59^{\circ} \mathrm{C}$ for 30 seconds and $72^{\circ} \mathrm{C}$ for 90 seconds. The PCR procedure was terminated by a final extension at $72^{\circ} \mathrm{C}$ for $6 \mathrm{~min}$. Amplified 469 or $513 \mathrm{bp}$ fragments were electrophoresed through $2.0 \%$ agarose and visualized by ultraviolet illumination upon ethidium bromide staining.

Statistical Analyses. Data analysis was carried out using the statistical package for social studies (SPSS) version 17 (SPSS Inc., Chicago, IL, USA) to compute all de-scriptive statistics. The chi-squate $\left(\chi^{2}\right)$ test was used to identify the correlation between the studied demographic variables and PPD. If $n<5$, exact Fisher statistic test was used. In addition, the same tests were used to evaluate the genotype distribution and allele frequencies of the three studied polymorphisms. The test power was calculated for allele and genotype frequencies using Power and Sample Size Calculation Program (PS version 3.0.1; Vanderbilt University Medical Center, Nashville, TN, USA). For all analyses, the power was more than $75.0 \%$. A $p$ value $<0.05$ was considered significant. The Hardy-Weinberg equilibrium was assessed using the $\chi^{2}$ test.

\section{RESULTS}

This study included 370 postpartum women aged between 17 to 45 years old. Almost all the women were married (99.5\%), more than half of them (62.2\%) were aged less than or equal to 30 years, and about $80.0 \%$ had completed their education with at least a high school certificate. The majority of women were homemakers $(86.6 \%)$ and most were not satisfied with their income adequacy (74.1\%). Demographic variables are shown in Tables 1, 2 and 3.

About $35.0 \%$ of postpartum women scored 13 or higher on the EPDS, thus a considerable fraction of the participating women had PPD, of whom $29.2 \%$ had a previous history of depression. Several psychosocial variables were examined for their association with PPD including: marital status, depression history and living status, whether with husband and children only or in the household of their husband's family. Among these factors, only the history of depression was found to be highly significantly associated with PPD ( $p<0.001$, Table 1). However, divorced women were only found

Table 1. The correlation between psychosocial variables and postpartum depression.

\begin{tabular}{|l|c|c|c|}
\hline Parameters & $\begin{array}{c}\text { Normal } \\
\boldsymbol{n}(\boldsymbol{\%})\end{array}$ & $\begin{array}{c}\text { Depressed } \\
\boldsymbol{n}(\boldsymbol{\%})\end{array}$ & $\begin{array}{c}\text { Total } \\
\boldsymbol{n}(\boldsymbol{\%})\end{array}$ \\
\hline $\begin{array}{l}\text { History of depression } \\
\text { yes }\end{array}$ & $31(12.9)$ & $38(29.2)$ & $69(18.6)$ \\
no & $209(87.1)$ & $92(70.8)$ & $301(81.4)$ \\
\hline $\begin{array}{l}\text { Marital status } \\
\text { married }\end{array}$ & $240(100.0)$ & $128(98.5)$ & $368(99.5)$ \\
divorced & $0(0.0)$ & $2(1.5)$ & $2(0.5)$ \\
\hline Living status & $223(92.9)$ & $119(91.5)$ & 0.054 \\
with husband's family & $17(7.1)$ & $11(8.5)$ & $342(92.5)$ \\
with husband and children only & & $28(7.5)$ \\
\hline
\end{tabular}


Table 2. The correlation between intra-partum variables and postpartum depression.

\begin{tabular}{|c|c|c|c|c|}
\hline Parameters & $\begin{array}{c}\text { Normal } \\
n(\%)\end{array}$ & $\begin{array}{c}\text { Depressed } \\
n(\%) \\
\end{array}$ & $\begin{array}{c}\text { Total } \\
n(\%) \\
\end{array}$ & $p$ Value \\
\hline $\begin{array}{l}\text { Delivery mode } \\
\text { normal } \\
\text { Cesarean section }\end{array}$ & $\begin{array}{c}198(82.5) \\
42(17.5)\end{array}$ & $\begin{array}{c}105(80.8) \\
25(19.2)\end{array}$ & $\begin{array}{c}303(81.9) \\
67(18.1)\end{array}$ & 0.680 \\
\hline $\begin{array}{l}\text { Pregnancy problems }^{\mathbf{a}} \\
\text { yes } \\
\text { no }\end{array}$ & $\begin{array}{r}34(14.2) \\
206(85.8) \\
\end{array}$ & $\begin{array}{r}29(23.3) \\
101(76.7) \\
\end{array}$ & $\begin{array}{r}63(17.0) \\
307(83.0) \\
\end{array}$ & 0.047 \\
\hline $\begin{array}{l}\text { Breast feeding } \\
\text { yes } \\
\text { no } \\
\end{array}$ & $\begin{array}{r}221(92.1) \\
19(17.9) \\
\end{array}$ & $\begin{array}{c}122(93.8) \\
8(6.2)\end{array}$ & $\begin{array}{c}343(92.7) \\
27(7.3) \\
\end{array}$ & 0.534 \\
\hline $\begin{array}{l}\text { Planning pregnancy } \\
\text { yes } \\
\text { no }\end{array}$ & $\begin{array}{r}169(70.4) \\
71(29.6)\end{array}$ & $\begin{array}{l}86(66.2) \\
44(33.8)\end{array}$ & $\begin{array}{l}255(68.9) \\
115(31.1)\end{array}$ & 0.398 \\
\hline $\begin{array}{l}\text { Taking vitamins } \\
\text { yes } \\
\text { no }\end{array}$ & $\begin{array}{c}233(97.1) \\
7(2.9)\end{array}$ & $\begin{array}{c}125(96.2) \\
4(3.8)\end{array}$ & $\begin{array}{c}358(96.8) \\
11(3.2)\end{array}$ & 0.394 \\
\hline $\begin{array}{l}\text { Number of children } \\
1-3 \\
4-6 \\
>6\end{array}$ & $\begin{array}{c}162(67.5) \\
63(26.3) \\
15(6.2)\end{array}$ & $\begin{array}{c}82(63.1) \\
39(30.0) \\
9(6.9)\end{array}$ & $\begin{array}{c}244(65.9) \\
102(27.6) \\
24(6.5)\end{array}$ & 0.691 \\
\hline $\begin{array}{l}\text { Baby's sex } \\
\text { males } \\
\text { females }\end{array}$ & $\begin{array}{l}125(52.1) \\
115(47.9)\end{array}$ & $\begin{array}{l}63(48.5) \\
67(51.5)\end{array}$ & $\begin{array}{l}188(50.8) \\
182(49.2)\end{array}$ & 0.506 \\
\hline
\end{tabular}

a Pregnancy problems included hypertension, hypo/hyperglycemia, bleeding, edema, problems in thyroid secretion and others.

Table 3. The correlation between some socio-demographic variables and postpartum depression.

\begin{tabular}{|c|c|c|c|c|}
\hline Parameters & $\begin{array}{c}\text { Normal } \\
n(\%)\end{array}$ & $\begin{array}{c}\text { Depressed } \\
n(\%) \\
\end{array}$ & $\begin{array}{c}\text { Total } \\
n(\%) \\
\end{array}$ & $p$ Value \\
\hline $\begin{array}{l}\text { Age of mother } \\
<30 \text { years old } \\
>30 \text { years old }\end{array}$ & $\begin{array}{r}152(63.3) \\
88(36.7)\end{array}$ & $\begin{array}{l}78(60.0) \\
52(40.0)\end{array}$ & $\begin{array}{l}230(62.2) \\
140(27.8)\end{array}$ & 0.376 \\
\hline $\begin{array}{l}\text { Education level } \\
<\text { secondary } \\
\text { secondary certificate } \\
\text { college ( } 2 \text { years) } \\
\text { university or more }\end{array}$ & $\begin{array}{r}45(18.7) \\
112(46.7) \\
47(19.6) \\
36(15.0)\end{array}$ & $\begin{array}{l}30(23.1) \\
66(50.8) \\
18(13.8) \\
16(12.3)\end{array}$ & $\begin{array}{r}75(20.3) \\
178(48.1) \\
65(17.6) \\
52(14.0)\end{array}$ & 0.378 \\
\hline $\begin{array}{l}\text { Employment status } \\
\text { working } \\
\text { homemaker }\end{array}$ & $\begin{array}{r}31(12.9) \\
209(87.1)\end{array}$ & $\begin{array}{r}18(13.8) \\
112(84.2)\end{array}$ & $\begin{array}{r}49(13.2) \\
321(86.8)\end{array}$ & 0.459 \\
\hline $\begin{array}{l}\text { Income satisfaction } \\
\text { yes } \\
\text { no }\end{array}$ & $\begin{array}{r}71(29.6) \\
169(71.4)\end{array}$ & $\begin{array}{c}25(19.2) \\
105(80.8)\end{array}$ & $\begin{array}{r}96(25.6) \\
274(74.4)\end{array}$ & 0.030 \\
\hline
\end{tabular}

within the depressed women group (two cases), thus, marital status may be correlated to PPD but was only marginally significant ( $p$ value $=0.054)$.

Among the examined intra-partum variables, only the presence of maternal health problems (hypertension, hypo/ hyperglycemia, bleeding, edema, problems in thyroid secretion and others) was associated with PPD $(p<0.05$, Table 2$)$. With respect to socio-demographic variables, income satisfaction was significantly related to PPD $(p<0.05)$. Other socio-demographic variables including maternal age, educational level, and employment status were not associated with PPD (Table 3).

The genotype and allele frequencies of the SLC6A4 (L/S) and TPH1 polymorphisms are shown in Table 4. All genotypes of both polymorphisms 
Table 4. Genotype and allele frequencies of polymorphism among the participating women.

\begin{tabular}{|c|c|c|c|}
\hline Genotypes and Alleles & $\begin{array}{c}\text { Control Group } \\
n(\%)\end{array}$ & $\begin{array}{c}\text { Depressed Group } \\
n(\%)\end{array}$ & $p$ Value \\
\hline $\begin{array}{l}\text { SLC6A4 (5-HTTLPR) } \\
\text { LL } \\
\text { SL } \\
\text { SS }\end{array}$ & $\begin{array}{r}62(25.8) \\
124(51.7) \\
54(22.5)\end{array}$ & $\begin{array}{l}36(27.7) \\
59(45.4) \\
35(26.9)\end{array}$ & 0.480 \\
\hline $\begin{array}{l}\text { Allele L } \\
\text { Allele S }\end{array}$ & $\begin{array}{l}248(51.7) \\
232(48.3)\end{array}$ & $\begin{array}{l}131(50.4) \\
129(49.6)\end{array}$ & 0.887 \\
\hline $\begin{array}{l}\text { TPH1 (A218C) } \\
\text { AA } \\
\text { AC } \\
\text { CC }\end{array}$ & $\begin{array}{r}34(14.2) \\
116(48.3) \\
90(37.5)\end{array}$ & $\begin{array}{l}15(11.5) \\
61(46.9) \\
54(41.5)\end{array}$ & 0.661 \\
\hline $\begin{array}{l}\text { Allele A } \\
\text { Allele C }\end{array}$ & $\begin{array}{l}184(38.3) \\
296(61.7)\end{array}$ & $\begin{array}{r}91(35.0) \\
169(65.0)\end{array}$ & 0.768 \\
\hline
\end{tabular}

were in Hardy-Weinberg equilibrium. The distribution of both $\mathrm{S}$ and $\mathrm{L}$ alleles of the SLC6A4 (L/S) polymorphism is similar, and both are common among Jordanian women (about 51.0 and $49.0 \%$, respectively). With respect to the TPH1 polymorphism, allele $\mathrm{C}$ is more common than allele A (63.0 and $37.0 \%$, respectively). There was no significant association between the genotypes of either SLC6A4 (L/S) or TPH1 polymor-phisms and PPD in the studied population $(p>0.05$, Table 4$)$. Similarly, allele frequencies of the examined variations were not related to $\operatorname{PPD}(p$ $>0.05$, Table 4 ). Regarding $T P H 2$ polymorphism, the A allele was not detected in the investigated population, and therefore no analysis was performed.

\section{DISCUSSION}

Serotonin has been shown to be involved in many physiological and behavioral processes, including: mood, sleep and cognation [3]. In addition, alterations in the serotonergic system have been implicated in many neuropsychiatric disorders such as aggressive, suicidal behavior and depression $[4,25]$. In this study, we investigated the role of variations in SLC6A4, TPH1 and TPH2 genes with depression in Jordanian women during the postpartum period.

The results presented in this study reveal lack of association between the $\mathrm{TPH} 1$ polymorphism and PPD in the examined sample. In agreement with our results, Frisch et al. [26] found no association between the TPH1 polymorphism and unipolar affective disorder including depression. Similar results were reported by Serretti et al. [27] who failed to find any association between this polymorphism and mood disorders. In contrast, Sun et al. [28] reported significant association between the TPH1 gene polymorphism with depression, anxiety, and comorbid depression and anxiety in Taiwanese women during the postpartum period. In addition Porter et al. [22] reported an association between TPHI and reduced tryptophan levels in females but not in males and the subsequent predisposition to depression.

The results also showed absence of association between the $S L C 6 A 4$ (L/S) polymorphism and depression in postpartum Jordanian women. In agreement with our results, Middledorp et al. [24] suggested that SLC6A4 (L/S) has no direct association with neuroticism, anxiety and depression in The Netherlands. In addition, another two studies comprising 5,262 subjects failed to find any association between the $\mathrm{S}$ allele and stressful life events of social adversity [29,30]. However, a Spanish study found association between the Lallele and PPD [31]. Moreover, evidence pointing to a correlation between the $\mathrm{S}$ allele and increased risk of depression was found in females who had experienced chronic diseases [32]. Thus, association between examined polymorphisms and PPD might have a population-specific component being affected by genetic background and/or associated with certain conditions.

In the study sample, approximately $35.0 \%$ of women scored 13 or higher on the EPDS. Slightly lower prevalence rates were reported in other Arab countries including Dubai (17.8\%) and Beirut (16.0\%) $[33,34]$. A recent review of 143 studies comprising 40 countries has shown that the PPD rate may reach up to $60.0 \%$, especially in a low income population [34]. Thus, Jordan is ranked in the middle in countries in the prevalence of PPD. 
The result of the present study showed that depression history, income level and pregnancy complications were associated with PPD. This is in agreement with O'Hara et al. [35] and Beck et al. [2] who found a strong association between depression history and economic status with developing PPD. In addition Rich-Edward et al. [36] considered depression history as the most powerful risk factor in developing PPD. Moreover, high prevalence rates of PPD (25.0-50.0\%) was reported in a low income population [37]. Finally, some studies related PPD to the mother's health [38] and pregnancy problems [35]. The lack of association with other examined factors is consistent with previous studies that failed to find an association between PPD and maternal age, educational level $[2,35]$, marital status $[39,40]$, baby gender [41], delivery mode [40], breast-feeding and employment [36]. These results could be explained by a stable marital relationships as almost all participants were married and most of them were educated. In addition, the majority of them were homemakers and had enough time to do their work at home and take care of their children.

Postpartum depression is a complex disorder, which likely results from a combination between genetics as well as environmental factors. The contribution of environmental factors has stronger influence on PPD than genetics as the degree of PPD heritability seems to be weak [42]. Thus, the stronger influence of environmental factors on PPD might cover or minimize the weaker genetic effect. In addition, it is possible that we have other polymorphisms across the genes in the Jordanian population, which in turn, might modulate the effect of the studied polymorphisms. Therefore, additional molecular genetic studies are needed to screen possible modifier polymorphisms under the influence of environmental and other hormonal effectors.

In conclusion, the results of this study indicate that $S L C 6 A 4(\mathrm{~L} / \mathrm{S})$ and $T P H 1$ variations are not associated with the development of PPD in Jordanian women. In addition, the TPH $2 \mathrm{~A}$ allele was absent in the examined population.

\section{ACKNOWLEDGMENTS}

This study was supported by funds from the Deanship of Scientific Research in Jordan University of Science and Technology, grant number 5/2009 to OFK.

\section{REFERENCES}

1. Agampodi TC, Agampodi SB, Wickramasinghe WA, Adhikari AM, Chathurani HK. Post partum depression - a problem that needs urgent attention. Ceylon Med J. 2011; 56(4): 183-184.

2. Beck CT, Gable RK. Comparative analysis of the performance of the Postpartum Depression Screening Scale with two other depression instruments. Nurs Res. 2001; 50(4): 242-250.

3. Birdsall TC. 5-Hydroxytryptophan: a clinicallyeffective serotonin precursor. Altern Med Rev. 1998; 3(4): 271-280.

4. Richerson GB, Buchanan GF. The serotonin axis: shared mechanisms in seizures, depression, and SUDEP. Epilepsia. 2011; 52(Suppl 1): 28-38.

5. Rahman S, Khan IA, Thomas P. Tryptophan hydroxylase: a target for neuroendocrine disruption. J Tox-icol Environ Health B Crit Rev. 2011; 14(5-7): 473-494.

6. Craig SP, Boularand S, Darmon MC, Mallet J, Craig IW. Localization of human tryptophan hydroxylase (TPH) to chromosome 11p15.3----p14 by in situ hybridization. Cytogenet Cell Genet. 1991; 56(3-4): 157-159.

7. Walther DJ, Bader M. A unique central tryptophan hydroxylase isoform. Biochem Pharmacol. 2003; 66(9): 1673-1680.

8. Jonsson EG, Goldman D, Spurlock G, Gustavsson JP, Nielsen DA, Linnoila M, et al. Tryptophan hydroxylase and catechol-O-methyltransferase gene polymorphisms: relationships to monoamine metabolite concentrations in CSF of healthy volunteers. Eur Arch Psychiatry Clin Neurosci. 1997; 247(6): 297-302.

9. Nielsen DA, Jenkins GL, Stefanisko KM, Jefferson KK, Goldman D. Sequence, splice site and population frequency distribution analyses of the polymorphic human tryptophan hydroxylase intron 7. Brain Res Mol Brain Res. 1997; 45(1): 145-148.

10. Chen GL, Miller GM. Advances in tryptophan hydroxylase-2 gene expression regulation: new insights into serotonin-stress interaction and clinical implications. Am J Med Genet B Neuropsychiatr Genet. 2012; 159B(2): 152-171.

11. Mokrovic G, Matosic A, Hranilovic D, Stefulj J, Novokmet M, Oreskovic D, et al. Alcohol 
dependence and polymorphisms of serotonin-related genes: association studies. Coll Antropol. 2008; 32(Suppl 1): 127-131.

12. Zhang X, Gainetdinov RR, Beaulieu JM, Sotnikova TD, Burch LH, Williams RB, et al. Loss-offunction mutation in tryptophan hydroxylase-2 identified in unipolar major depression. Neuron. 2005; 45(1): 11-16.

13. Egawa J, Watanabe Y, Nunokawa A, Endo T, Kaneko N, Tamura R, et al. A detailed association analysis between the tryptophan hydroxylase 2 (TPH2) gene and autism spectrum disorders in a Japanese population. Psychiatry Res. 2012; 196(2-3): 320-322.

14. Fudalej S, Ilgen M, Fudalej M, Kostrzewa G, Barry K, Wojnar M, et al. Association between tryptophan hydroxylase 2 gene polymorphism and completed suicide. Suicide Life Threat Behav. 2010; 40(6): 553-560.

15. Ramamoorthy S, Cool DR, Mahesh VB, Leibach FH, Melikian HE, Blakely RD, et al. Regulation of the human serotonin transporter. Cholera toxin-induced stimulation of serotonin uptake in human placental choriocarci-noma cells is accompanied by increased serotonin transporter mRNA levels and serotonin transporter-specific ligand binding. J Biol Chem. 1993; 268(29): 21626-21631.

16. Heils A, Teufel A, Petri S, Stober G, Riederer P, Bengel $\mathrm{D}$, et al. Allelic variation of human serotonin transporter gene expression. J Neurochem. 1996; 66(6): 2621-2624.

17. Wray NR, James MR, Gordon SD, Dumenil T, Ryan L, Coventry WL, et al. Accurate, Largescale genotyping of 5HTTLPR and flanking single nucleotide poly-morphisms in an association study of depression, anxiety, and personality measures. Biol Psychiatry. 2009; 66(5): 468-476.

18. Cervilla JA, Molina E, Rivera M, Torres-Gonzalez F, Bellon JA, Moreno B, et al. The risk for depression conferred by stressful life events is modified by variation at the serotonin transporter 5HTTLPR genotype: evidence from the Spanish PREDICT-Gene cohort. Mol Psychiatry. 2007; 12(8): 748-755.

19. Coventry WL, James MR, Eaves LJ, Gordon SD, Gillespie NA, Ryan L, et al. Do 5HTTLPR and stress interact in risk for depression and suici- dality? Item response analyses of a large sample. Am J Med Genet B Neuro-psychiatr Genet. 2010; 153B(3): 757-765.

20. Shinozaki G. The integrated model of serotonin transporter gene variation (5HTTLPR) and the glial cell transporter in stress vulnerability and depression. Med Hypotheses. 2012; 78(3): 410-414.

21. Cox JL, Holden JM, Sagovsky R. Detection of postnatal depression. Development of the 10item Edinburgh Postnatal Depression Scale. Br J Psychiatry. 1987; 150(6): 782-786.

22. Porter RJ, Gallagher P, O'Brien JT. Effects of rapid tryptophan depletion on salivary cortisol in older people recovered from depression, and the healthy elderly. J Psychopharmacol. 2007; 21(1): 71-75.

23. Khabour OF, Mesmar FS, Al-Tamimi F, AlBatay-neh OB, Owais AI. Missense mutation of the EDA gene in a Jordanian family with $\mathrm{X}$-linked hypohidrotic ectodermal dysplasia: phenotypic appearance and speech problems. Genet Mol Res. 2010; 9(2): 941-948.

24. Middeldorp CM, de Geus EJ, Beem AL, Lakenberg N, Hottenga JJ, Slagboom PE, et al. Family based association analyses between the serotonin transporter gene polymorphism (5-HTTLPR) and neuroticism, anxiety and depression. Behav Genet. 2007; 37(2): 294-301.

25. Mansour HA, Talkowski ME, Wood J, Pless L, Bamne M, Chowdari KV, et al. Serotonin gene polymor-phisms and bipolar I disorder: focus on the serotonin transporter. Ann Med. 2005; 37(8): 590-602.

26. Frisch A, Postilnick D, Rockah R, Michaelovsky E, Postilnick S, Birman E, et al. Association of unipolar major depressive disorder with genes of the serotonergic and dopaminergic pathways. Mol Psychiatry. 1999; 4(4): 389-392.

27. Serretti A, Cristina S, Lilli R, Cusin C, Lattuada $\mathrm{E}$, Lorenzi $\mathrm{C}$, et al. Family-based association study of 5-HTTLPR, TPH, MAO-A, and DRD4 polymorphisms in mood disorders. Am J Med Genet. 2002; 114(4): 361-369.

28. Sun HS, Tsai HW, Ko HC, Chang FM, Yeh TL. Association of tryptophan hydroxylase gene polymorphism with depression, anxiety and comor- 
bid depression and anxiety in a population-based sample of postpartum Taiwanese women. Genes Brain Behav. 2004; 3(6): 328-336.

29. Gillespie NA, Whitfield JB, Williams B, Heath AC, Martin NG. The relationship between stressful life events, the serotonin transporter (5-HTTLPR) genotype and major depression. Psychol Med. 2005; 35(1): 101-111.

30. Surtees PG, Wainwright NW, Willis-Owen SA, Luben R, Day NE, Flint J. Social adversity, the serotonin transporter (5-HTTLPR) polymorphism and major depressive disorder. Biol Psychiatry. 2006; 59(3): 224-229.

31. Sanjuan J, Martin-Santos R, Garcia-Esteve L, Carot JM, Guillamat R, Gutierrez-Zotes A, et al. Mood changes after delivery: role of the serotonin transporter gene. Br J Psychiatry. 2008; 193(5): 383-388.

32. Grabe HJ, Lange M, Wolff B, Volzke H, Lucht M, Freyberger HJ, et al. Mental and physical distress is modulated by a polymorphism in the 5-HT transporter gene interacting with social stressors and chronic disease burden. Mol Psychiatry. 2005; 10(2): 220-224.

33. Chaaya M, Campbell OM, El Kak F, Shaar D, Harb H, Kaddour A. Postpartum depression: prevalence and determinants in Lebanon. Arch Womens Ment Health. 2002; 5(2): 65-72.

34. Halbreich U, Karkun S. Cross-cultural and social diversity of prevalence of postpartum depression and depressive symptoms. J Affect Disord. 2006; 91(2-3): 97-111.

35. O'Hara MW, Schlechte JA, Lewis DA, Varner MW. Controlled prospective study of postpartum mood disorders: psychological, environmental, and hormonal variables. J Abnorm Psychol. 1991; 100(1): 63-73.

36. Rich-Edwards JW, Kleinman K, Abrams A, Harlow BL, McLaughlin TJ, Joffe H, et al. Sociodemo-graphic predictors of antenatal and postpartum depressive symptoms among women in a medical group practice. J Epidemiol Community Health. 2006; 60(3): 221-227.

37. Chung EK, McCollum KF, Elo IT, Lee HJ, Culhane JF. Maternal depressive symptoms and infant health practices among low-income women. Pediatrics. 2004; 113(6): e523-e529.

38. Gjerdingen DK, Chaloner KM. The relationship of women's postpartum mental health to employment, childbirth, and social support. J Fam Pract. 1994; 38(5): 465-472.

39. Chaudron LH, Klein MH, Remington P, Palta M, Allen C, Essex MJ. Predictors, prodromes and incidence of postpartum depression. J Psychosom Obstet Gynaecol. 2001; 22(2): 103-112.

40. Josefsson A, Angelsioo L, Berg G, Ekstrom CM, Gunnervik C, Nordin C, et al. Obstetric, somatic, and demographic risk factors for postpartum depressive symptoms. Obstet Gynecol. 2002; 99(2): 223-228.

41. Husain N, Bevc I, Husain M, Chaudhry IB, Atif N, Rahman A. Prevalence and social correlates of postnatal depression in a low income country. Arch Womens Ment Health. 2006; 9(4): 197-202.

42. Sullivan PF, Neale MC, Kendler KS. Genetic epidemiology of major depression: review and meta-analysis. Am J Psychiatry. 2000; 157(10): 1552-1562. 